\title{
Calcined Low-grade Clays as Sources for Zeolite Containing Material
}

\author{
Nailia R. Rakhimova ${ }^{1 *}$, Ravil Z. Rakhimov², Vladimir P. Morozov ${ }^{3}$ Aleksey A. Eskin ${ }^{3}$ \\ ${ }^{1}$ Sustainable Developments in Civil Engineering Research Group, Faculty of Civil Engineering, Ton Duc Thang University, 700000 Ho \\ Chi Minh City, Vietnam \\ 2 Department of Building Materials, Kazan State University of Architecture and Engineering, 420043 Kazan, Russian Federation \\ ${ }^{3}$ Department of Mineralogy and Lithology, Kazan Federal University, 420008 Kazan, Russian Federation \\ * Corresponding author, e-mail: nailia.rakhimova@tdtu.edu.vn
}

Received: 26 March 2019, Accepted: 28 September 2020, Published online: 27 October 2020

\begin{abstract}
The continuous development and expansion of a raw material base in response to increasing environmental and technical requirements for most consumable commodities are crucial for the sustainable development of resource- and energy-intensive materials and technologies. As the sources for alkali-activated cements and zeolites, recent studies have reported the suitability of applying calcined clays with various chemical compositions, percentages, and constituent clay minerals and secondary minerals. In this article, the results of a feasibility study on the alkali activation of low-grade clays with $7.26 \%$ montmorillonite/chlorite and $23.14 \%$ kaolinite/ montmorillonite minerals are reported. The $6 \mathrm{M} \mathrm{NaOH}$ activation of clays thermally treated at $700{ }^{\circ} \mathrm{C}$ results in the formation of a hardened paste with a compressive strength of up to $5 \mathrm{MPa}$, with an $\mathrm{N}$-(A)-S-H binder gel and zeolite $\mathrm{Na}_{2} \mathrm{Al}_{2} \mathrm{Si}_{2.5} \mathrm{O}_{9} \cdot 6.2 \mathrm{H}_{2} \mathrm{O}$ being the main reaction products.
\end{abstract}

Keywords

clay, calcination, cement, zeolite

\section{Introduction}

The demand for inorganic binders has increased in recent years, not only for use in building construction materials $[1,2]$ but also for other industries with diverse requirements [3]. Meanwhile, the development and production of cement as a binder meeting the increasing ecological and technical needs for various uses has necessitated changes in the raw material base. To this end, the use of calcined clays in both environmentally oriented low-clinker blended Portland cements and in non-clinker alkali-activated cements has significantly increased in recent decades owing to their availability, spreadability, raw value, and technical efficiency [4]. The application of thermally treated clays, which have been established as affordable alternatives to the expensive chemical sources of silica and alumina, in the production of valuable and multifunctional products has also increased [5]. Their suitability in forming aluminosilicates with a three-dimensional framework through a low-cost hydrothermal synthesis has made calcined clays useful products in the development of pure zeolites and alkali-activated cements [6], which comprises zeolites under certain conditions. From a compositional perspective, clays are extremely diverse materials and differ in their chemical compositions, percentages, and types of clay and non-clay minerals and impurities present, among other factors. In this regard, high-grade kaolin clays with a 1:1 kaolinite content of over $65 \%$ are considered the most valuable resource for obtaining pure and highly reactive amorphous metakaolin for various purposes. However, among the major global industrial mineral resources, $90 \%$ of the clays employed in production are 2:1 layer-lattice minerals, whereas only $10 \%$ are kaolin or bentonite clays [7]. To expand the range of available clay resources, a number of studies have recently been conducted. Such studies have demonstrated the suitability of various thermally treated clays, including medium- (40-65\%) and low-grade $(<40 \%)$ kaolin clays, as well as multimineral clays consisting of kaolin and/or non-kaolin clay minerals and non-clay minerals as precursors for alkali-activated materials [8-10] and as sources for the synthesis of zeolites through an alkali hydrothermal process [11, 12]. Although 
several studies have been conducted, those focusing on low-grade clays comprising less than $25 \%$ clay minerals have been less comprehensive [13-15].

This study aims to examine the potential application of low-grade calcined clays at 600,700 , and $800{ }^{\circ} \mathrm{C}$ with $7.26 \%$ 2:1 layer-lattice clay minerals and $23.14 \% 1: 1+2: 1$ layer-lattice clay minerals for alkali activation.

\section{Experimental details}

\subsection{Materials}

The clays used in this study were obtained from deposits in the Republic of Tatarstan (Russian Federation). The chemical and mineralogical compositions of the clays are presented, respectively, in Tables 1 and 2 .

According to Table 2 clay 1 is comprised of $7.26 \%$ of clay minerals including 2:1 layer-lattice montmorillonite and chlorite minerals, while Clay 2 contains $23.14 \%$ of $1: 1$ layer-lattice kaolinite and 2:1 layer-lattice montmorillonite and chlorite clay minerals.

Table 1 Chemical composition of clays

\begin{tabular}{|c|c|c|}
\hline \multirow{2}{*}{ Component (mass \% as oxide) } & \multicolumn{2}{|c|}{ Clay } \\
\hline & Clay 1 & Clay 2 \\
\hline $\mathrm{SiO}_{2}$ & 62.69 & 64.80 \\
\hline $\mathrm{TiO}_{2}$ & 0.72 & 1.22 \\
\hline $\mathrm{Al}_{2} \mathrm{O}_{3}$ & 10.7 & 20.60 \\
\hline $\mathrm{Fe}_{2} \mathrm{O}_{3}$ & 4.15 & 2.31 \\
\hline $\mathrm{MnO}$ & 0.08 & 0.01 \\
\hline $\mathrm{CaO}$ & 8.68 & 0.51 \\
\hline $\mathrm{MgO}$ & 1.80 & 0.52 \\
\hline $\mathrm{Na}_{2} \mathrm{O}$ & 1.04 & 0.18 \\
\hline $\mathrm{K}_{2} \mathrm{O}$ & 2.16 & 0.79 \\
\hline $\mathrm{P}_{2} \mathrm{O} 5$ & 0.08 & 0.05 \\
\hline $\mathrm{SO}_{3}$ & 0.05 & 0.05 \\
\hline LOI & 7.46 & 8.57 \\
\hline
\end{tabular}

Table 2 Mineralogical composition of clays

\begin{tabular}{lcc}
\hline Minerals (wt\%) & \multicolumn{2}{c}{ Clay } \\
\hline Chlorite & 2.38 & Clay 2 \\
Montmorillonite & 4.88 & - \\
Kaolinite & - & 8.71 \\
Calcite & 3.37 & 14.43 \\
Quartz & 30.44 & - \\
Dolomite & 1.04 & 26.73 \\
Feldspars & 15.41 & - \\
Amorphous phase & 33 & 4.26 \\
Clay minerals & 7.26 & 35 \\
\hline
\end{tabular}

The alkaline activator commercial sodium hydroxide pellets were obtained from Meterra (Russian Federation).

The details of the size distributions of calcined and milled clays are given in Fig. 1. The specific surface areas of Clays 1,2 were $6642,6925 \mathrm{~cm}^{2} / \mathrm{g}$ (Blaine), respectively. A substantial $82 \%$ of the clay particles were $<45 \mu \mathrm{m}$ and $35 \%$ were $<10 \mu \mathrm{m}$.

\subsection{Methods}

The chemical composition of the clays was determined using atomic emission spectrometry (OPTIMA 4300 DV). The particle size distribution of the clays was measured using a laser particle size analyzer (Horiba La-950V2). Clays were dispersed via ultrasound in ethanol and dispersion medium.

The clays were calcined at 600,700 , and $800^{\circ} \mathrm{C}$ for $5 \mathrm{~h}$ using heating rates of $1.7,2.5$ and $3.3^{\circ} \mathrm{C} / \mathrm{min}$, respectively, and milled in a planetary mill MPL-1.

The $6 \mathrm{M} \mathrm{NaOH}$ solution was prepared by dissolving of $\mathrm{NaOH}$ pellets in deionized water and cooling down to room temperature during $24 \mathrm{~h}$ prior to use.

The calcined clay samples were kneaded for about $10 \mathrm{~min}$ with alkaline activators solution at liquid/ratio of 0.45 to form pastes. The pastes were manually cast into $50 \times 50 \times 50 \mathrm{~mm}$ cubic moulds and vibrated to remove entrapped air. The compressive strength of the cubes was tested after steam curing, following a treatment program of $24 \mathrm{~h}$ of pre-setting, $4 \mathrm{~h}$ to reach the desired temperature, $6 \mathrm{~h}$ of dwell time at $85^{\circ} \mathrm{C}$ and $3 \mathrm{~h}$ cooling. Compression tests were performed by applying a load between the two surfaces that were vertical during casting. Each strength determination quoted is based on an average of six measurements from the same cast. Standard deviation and coefficient of variation were 0.175 and $5.984 \%$, respectively.

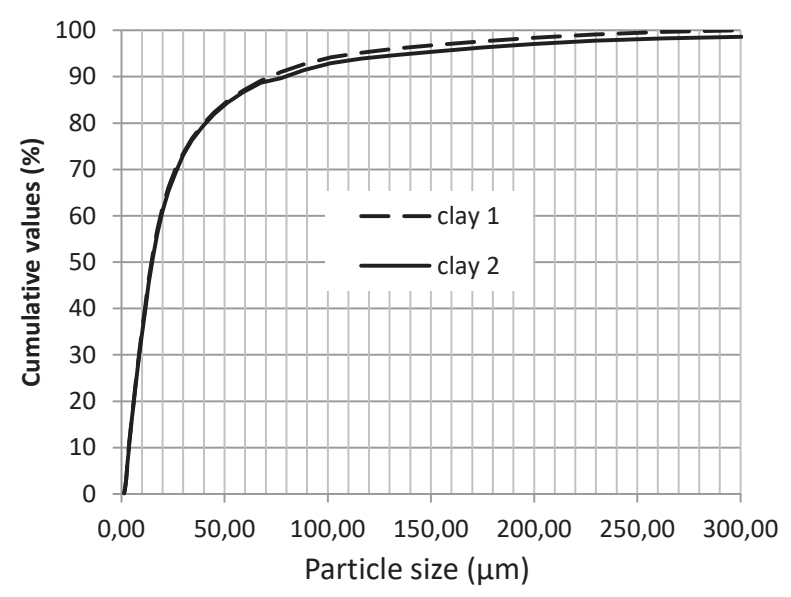

Fig. 1 Particle size distribution of clays 
X-ray diffraction (XRD) and thermal analyses (TG/ DSC) were performed on finely ground clays and samples of hardened pastes that had been steam cured. The XRD data were collected using a D2 Phaser X-ray diffractometer in a Bragg-Brentano $\theta-2 \theta$ configuration with a $\mathrm{Cu} \mathrm{K} \alpha$ radiation, operating at $40 \mathrm{kV}$ and $30 \mathrm{~mA}$. The data analysis was performed using the DIFFRAC plus Evaluation Package EVA Search/Match and the PDF-2 ICDD database. The mineralogical composition analysis of clays was estimated by analyzing the X-ray diffractograms in the software product Diffrac.eva V3.2. The quantification of the different phases is determined by the Rietveld method. An STA 443 F3 Jupiter simultaneous thermal analysis apparatus was used for TG/DSC. The samples were heated from $30^{\circ} \mathrm{C}$ to $1000^{\circ} \mathrm{C}$ at a heating rate of $10^{\circ} \mathrm{C} / \mathrm{min}$. The data was analyzed using Netzsch Proteus Thermal Analysis. FTIR spectra were recorded using a Spectrum 65 (PerkinElmer) ranging from 4000 to $650 \mathrm{~cm}^{-1}$.

\section{Results and discussion}

\subsection{Mechanical properties}

The influences of the calcination temperature and clay type on the compressive strength of hardened alkali-activated clay pastes are shown in Table 3. The compressive strength increases with an increase in the calcination temperature. Hardened pastes prepared using Clay 1 demonstrate a lower compressive strength that those prepared using Clay 2.

\subsection{Calcined clays characterization}

$\mathrm{X}$-ray, thermal analyses, and infrared spectroscopy were performed to reveal the changes in the clays composition during the thermal treatment.

Figs. 2 and 3 show XRD analysis results of Clays 1 and 2 in the raw and thermally treated states. As can be seen calcination at temperatures $600,700^{\circ} \mathrm{C}$ leads to decomposition and the disappearance of the peaks assigned to clay minerals - montmorillonite $(\mathrm{Na}, \mathrm{Ca}) \mathrm{Al}_{2}\left(\mathrm{Si}, \mathrm{Al}_{4}\right)_{10}(\mathrm{OH})_{2} \cdot \mathrm{H}_{2} \mathrm{O}$

Table 3 Compressive strength of hardened alkali-activated clay cement pastes (MPa)

\begin{tabular}{lcc}
\hline Clay & Calcination temperature $\left({ }^{\circ} \mathrm{C}\right)$ & Compressive strength $(\mathrm{MPa})$ \\
\hline \multirow{3}{*}{ Clay 1 } & 600 & 0.8 \\
& 700 & 2.5 \\
& 800 & 2.5 \\
\multirow{3}{*}{ Clay 2 } & 600 & 1.3 \\
& 700 & 4 \\
& 800 & 5 \\
\hline
\end{tabular}

chlorite $\left.\mathrm{Mg}_{2.96} \mathrm{Fe}_{1.55} \mathrm{Fe}_{0.136} \mathrm{Al}_{0.275}\right)\left(\mathrm{Si}_{2.622} \mathrm{Al}_{1.376} \mathrm{O}_{10}\right)(\mathrm{OH})_{8}$ in Clay 1 and kaolinite $\mathrm{Al}_{2} \mathrm{Si}_{2} \mathrm{O}_{5}(\mathrm{OH})_{4}$ and montmorillonite in Clay 2. Calcite $\mathrm{CaCO}_{3}$ and dolomite $\mathrm{Ca}\left(\mathrm{Ca}_{0.17} \mathrm{Mg}_{0.83}\right)$ $\left(\mathrm{CO}_{3}\right)$ present in the raw Clay 1 also decompose after calcination at $700^{\circ} \mathrm{C}$. The changes in the mica, layered silicates $\mathrm{KAl}_{2}\left(\mathrm{Si}, \mathrm{Al}_{4} \mathrm{O}_{10}(\mathrm{OH})_{2}\right.$, quartz $\mathrm{SiO}_{2}$, and feldspars $\left(\mathrm{K}_{0.95} \mathrm{Na}_{0.05}\right) \mathrm{AlSi}_{3} \mathrm{O}_{8}, \mathrm{~K}_{0.2} \mathrm{Na}_{0.8} \mathrm{AlSi}_{3} \mathrm{O}_{8}$ are negligible.

Figs. 4-7 demonstrate thermal analysis results. Endothermic peaks are detected for raw clays at $50^{\circ} \mathrm{C}-$ loss of adsorbed water, $130^{\circ} \mathrm{C}$ - loss of crystallization water by montmorillonite and kaolinite for both clays, in the range $430-560^{\circ} \mathrm{C}$ - dehydroxylation of kaolinite for Clay 2, in the range $600-720^{\circ} \mathrm{C}-$ decarbonation of calcite and dolomite for Clay 1.

TG analysis confirms these results - the highest weight losses for raw Clay 1 at $30-130(2.66 \%)$ and $600-720^{\circ} \mathrm{C}$ (2.81\%) are associated with clay and carbonate minerals, for raw Clay 2 at $30-120(1.59 \%)$ and $430-560^{\circ} \mathrm{C}(5.27 \%)$ are attributed to clay minerals.

Figs. 8 and 9 show the infrared spectroscopic results for clays in raw and calcined states.

The bands at $3363-3399,3619,3691 \mathrm{~cm}^{-1}$ and $1637-$ $1659 \mathrm{~cm}^{-1}$ representing the stretching and the deformation vibrations of $\mathrm{OH}-$ and $\mathrm{H}-\mathrm{O}-\mathrm{H}$ groups from water molecules are typical for polymeric structures, including aluminosilicate networks, and can be related to bound water in aluminosilicate minerals in raw a thermally treated clays [16]. The bands at $1024-1029 \mathrm{~cm}^{-1}$ and $1112 \mathrm{~cm}^{-1}$ reflect in-plane and out-of-plane stretching Si-O vibrations, respectively. The bands at 986 and $994 \mathrm{~cm}^{-1}$ are associated both with quartz, feldspar, and stretching vibrations of $\mathrm{Al}-\mathrm{O}$ and $\mathrm{Si}-\mathrm{O}$ in amorphous aluminosilicate structures [17]. The band at $908 \mathrm{~cm}^{-1}$ referring to $\mathrm{OH}$ and AlAlOH vibrations of crystalline kaolinite and montmorillonite [18] in raw Clay 2 disappear after calcination. The bands at $1420-1442 \mathrm{~cm}^{-1}$ and $874 \mathrm{~cm}^{-1}$, are observed in the spectra of clay 1, correspond to calcium carbonates [19]. Those signals are less intense in the calcined clay compared to the raw clay, due to the decomposition of calcite and dolomite at the thermal treatment. Vibrations at 776-778 and $692 \mathrm{~cm}^{-1}$ are attributed to quartz [20].

\subsection{Hardened pastes characterization}

The reacted systems based on the clays calcined at $700^{\circ} \mathrm{C}$ were studied by X-ray, thermal, and FTIR analyses.

The XRD patterns of the samples of hardened pastes are shown in Fig. 10. The relics of non-reacted quartz, feldspars, and layered silicates are identified in all the 


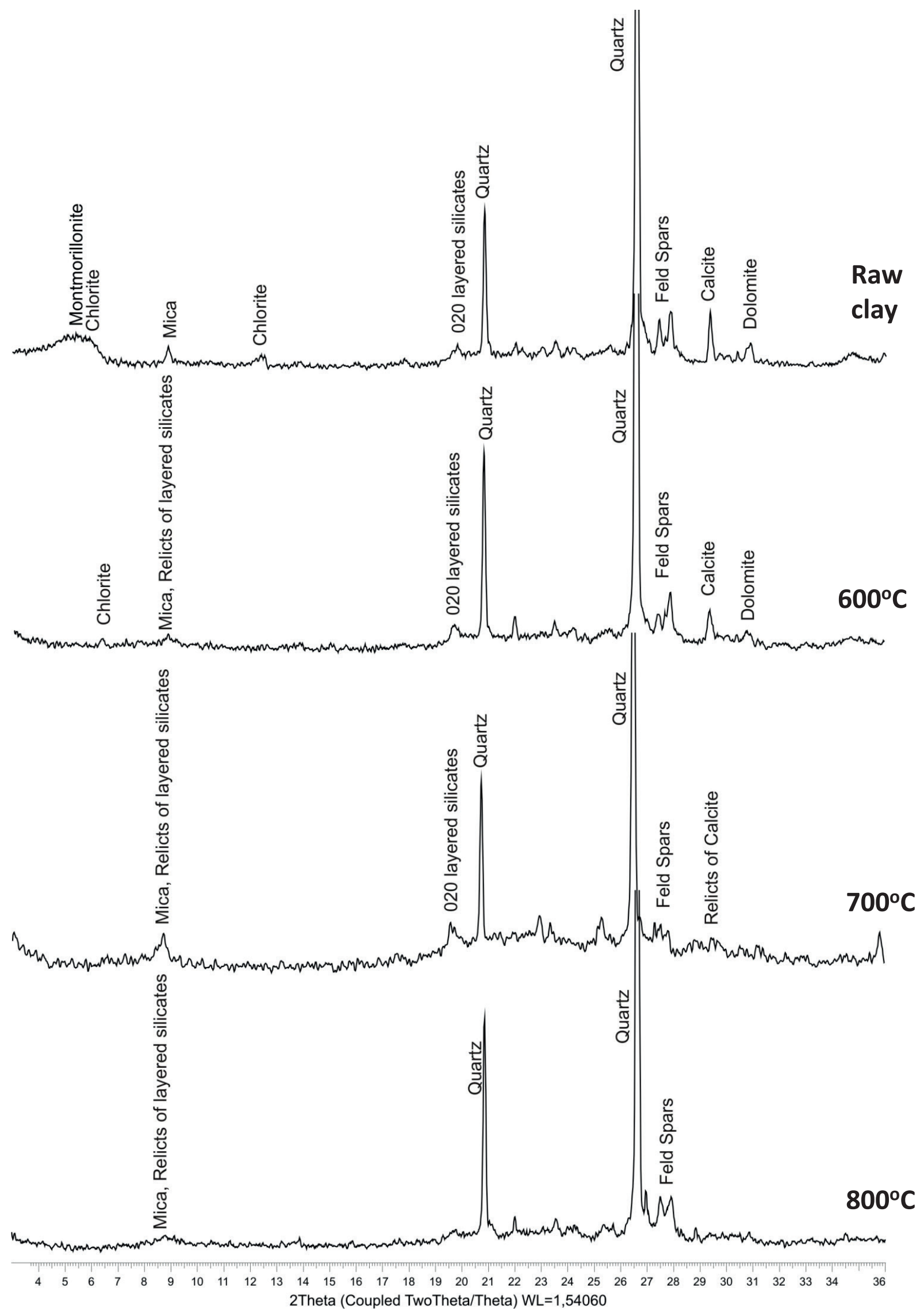

Fig. 2 X-ray diffractograms of raw Clay 1 and calcined at 600,700 , and $800^{\circ} \mathrm{C}$ 


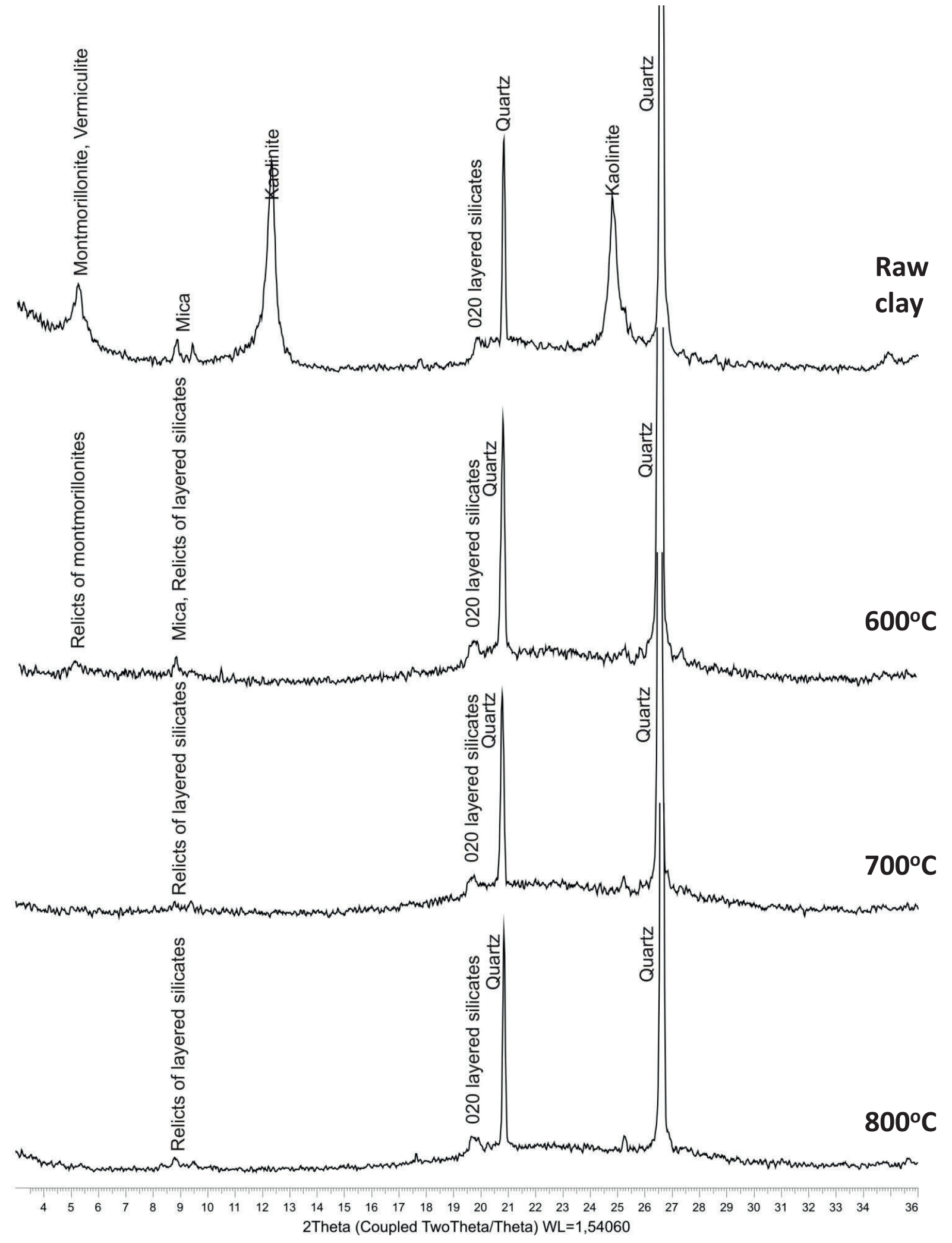

Fig. 3 X-ray diffractograms of raw Clay 2 and calcined at 600,700 , and $800^{\circ} \mathrm{C}$ 


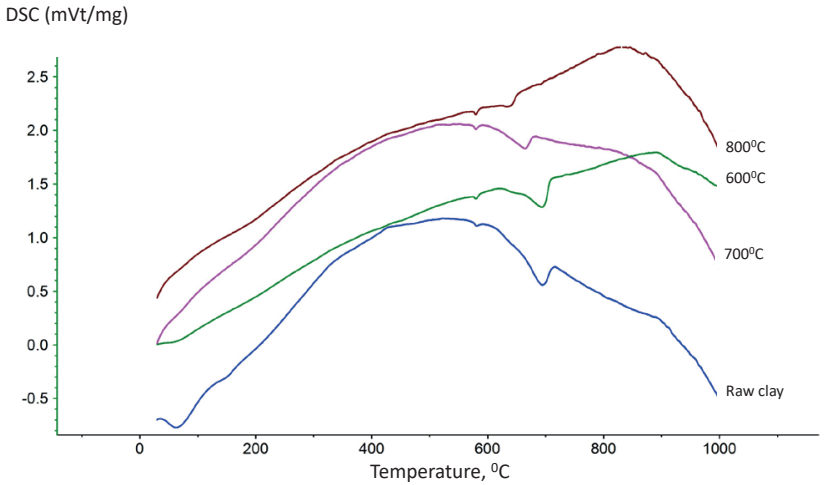

Fig. 4 DSC analysis of raw Clay 1 and calcined at 600,700 , and $800^{\circ} \mathrm{C}$

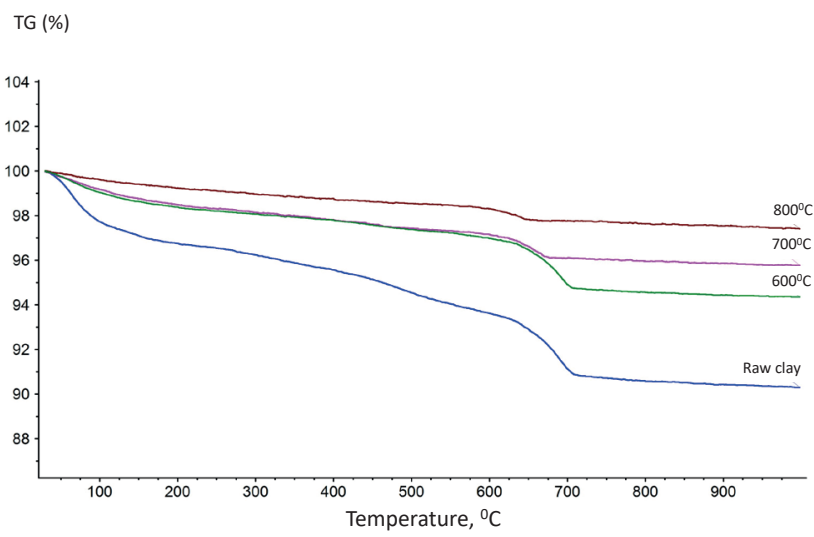

Fig. 5 TG analysis of raw Clay 1 and calcined at 600,700 , and $800^{\circ} \mathrm{C}$

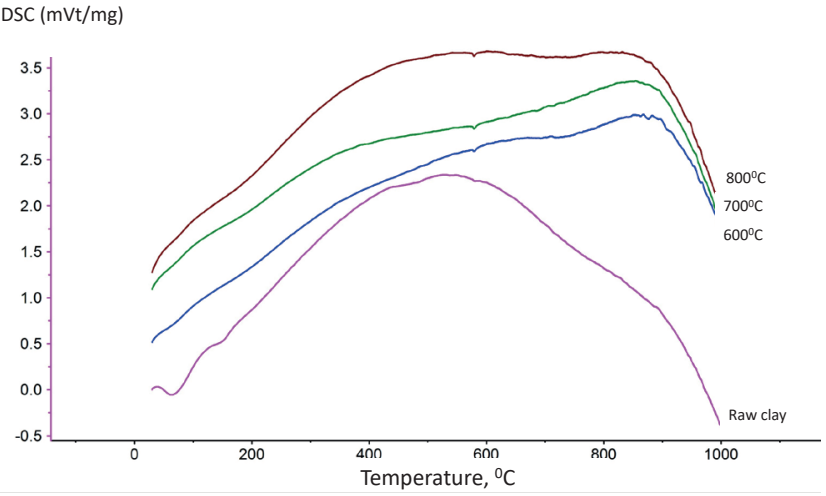

Fig. 6 DSC analysis of raw Clay 2 in raw state and calcined at 600, 700, and $800^{\circ} \mathrm{C}$

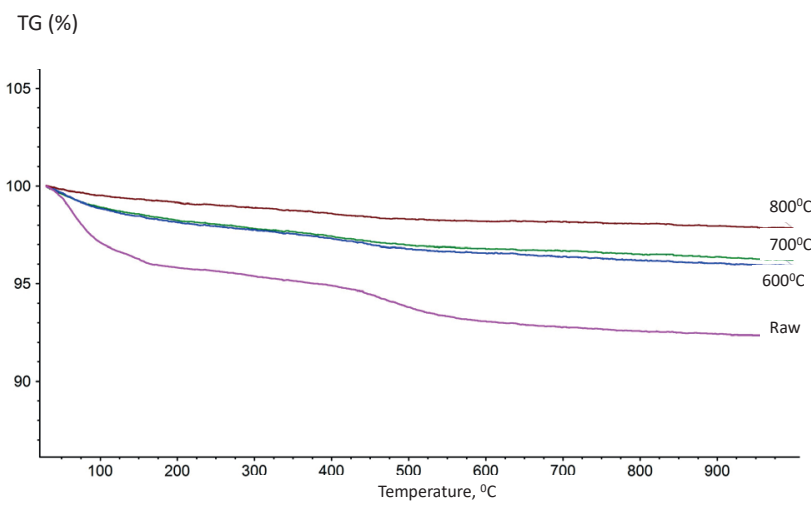

Fig. 7 TG analysis of raw Clay 2 and calcined at 600,700 , and $800^{\circ} \mathrm{C}$

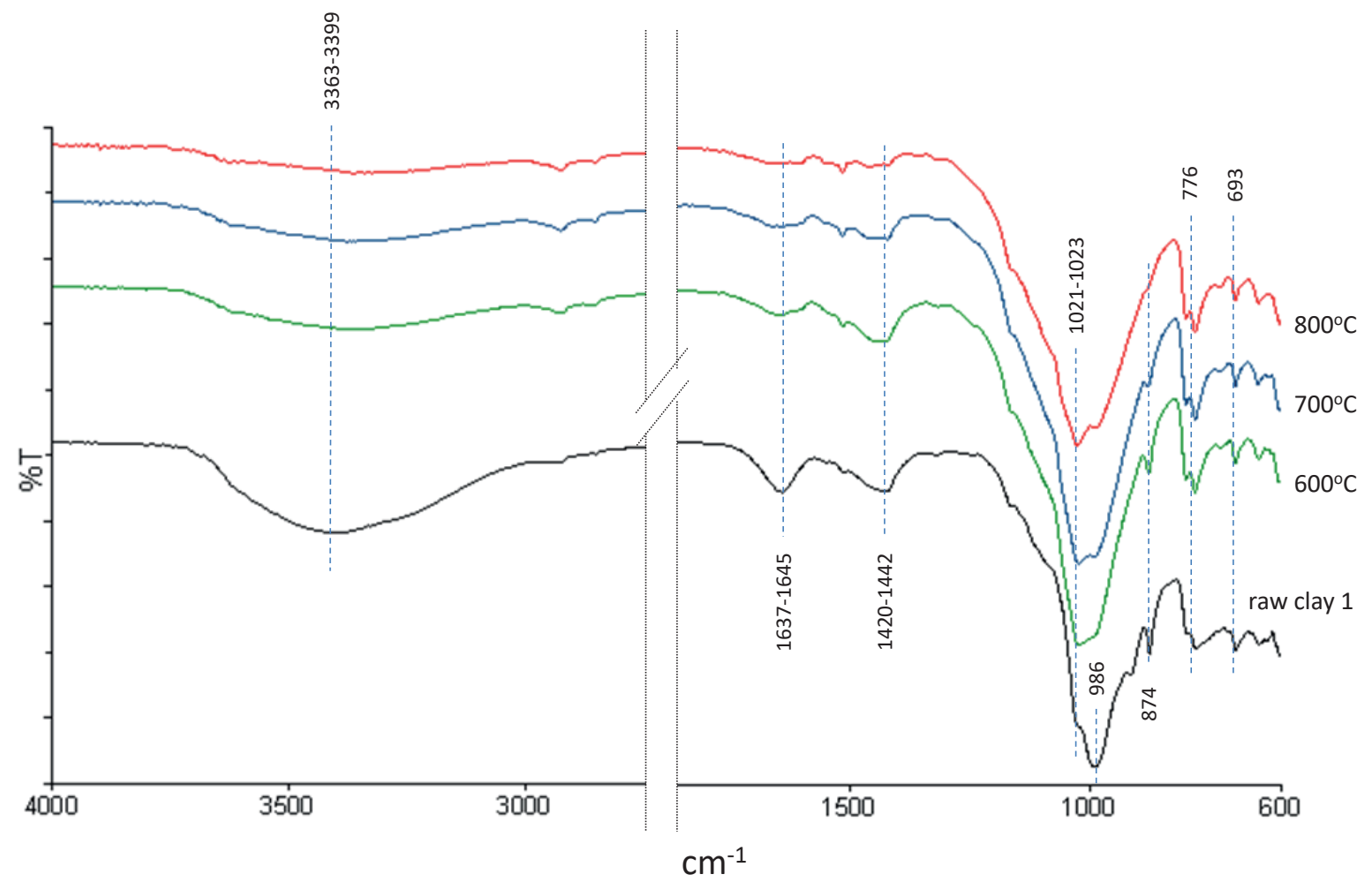

Fig. 8 FTIR spectra of raw Clay 1 and calcined at 600,700 , and $800^{\circ} \mathrm{C}$ 


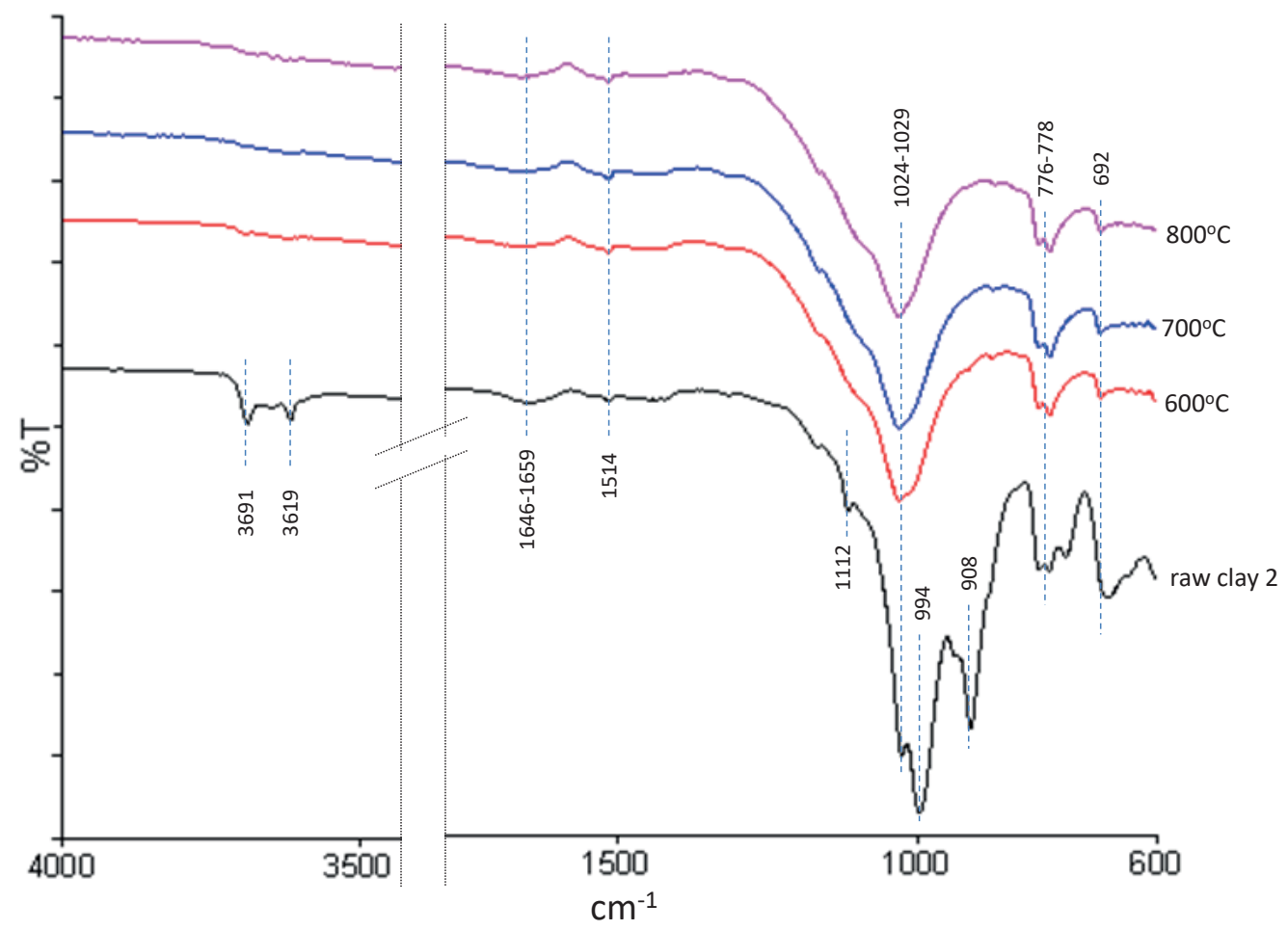

Fig. 9 FTIR spectra of raw Clay 1 and calcined at 600,700 , and $800^{\circ} \mathrm{C}$

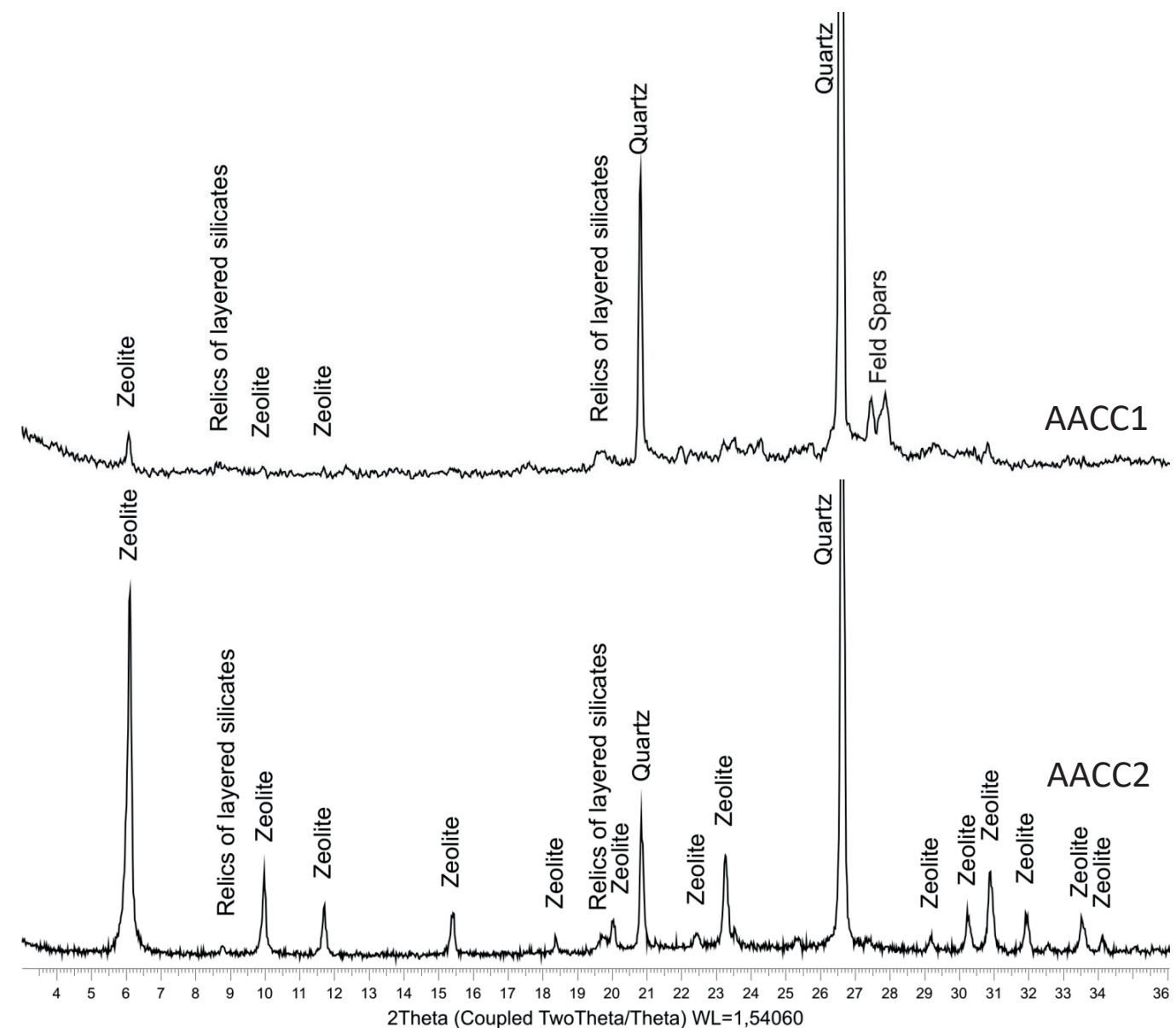

Fig. 10 X-ray diffractograms of AACC1 (based on calcined at $700^{\circ} \mathrm{C}$ Clay 1) and AACC2 (based on calcined at $700^{\circ} \mathrm{C}$ Clay 2) hardened pastes 


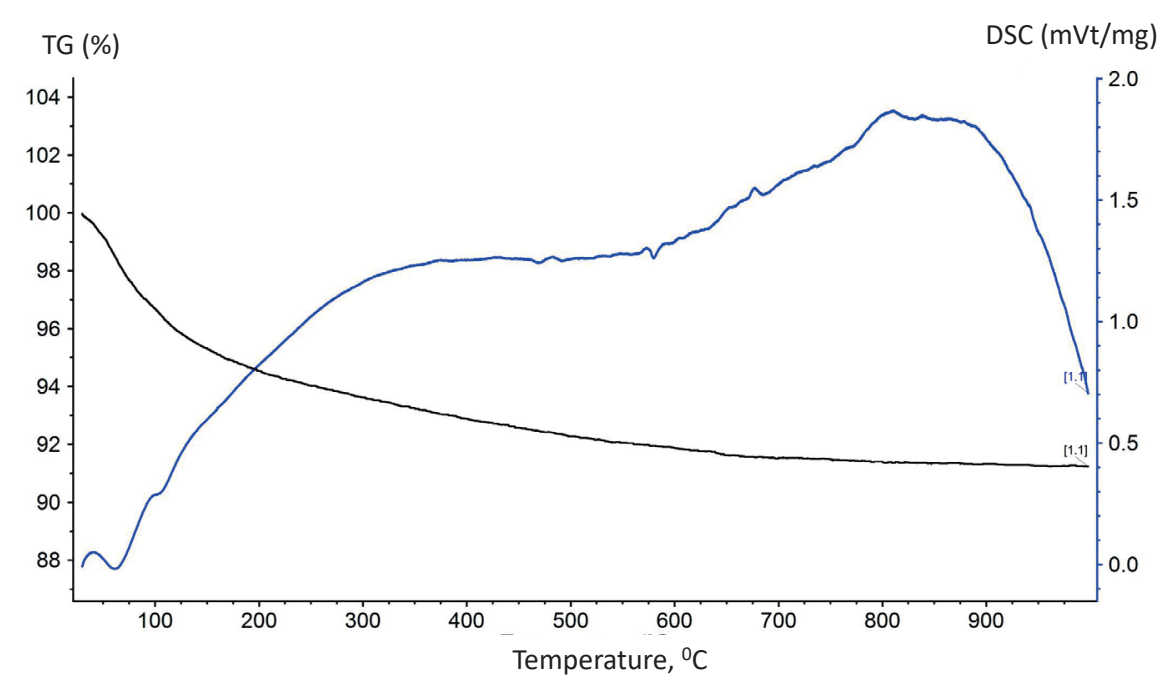

Fig. 11 Thermal analysis of AACC1 (based on calcined at $700^{\circ} \mathrm{C}$ Clay 1 ) hardened paste

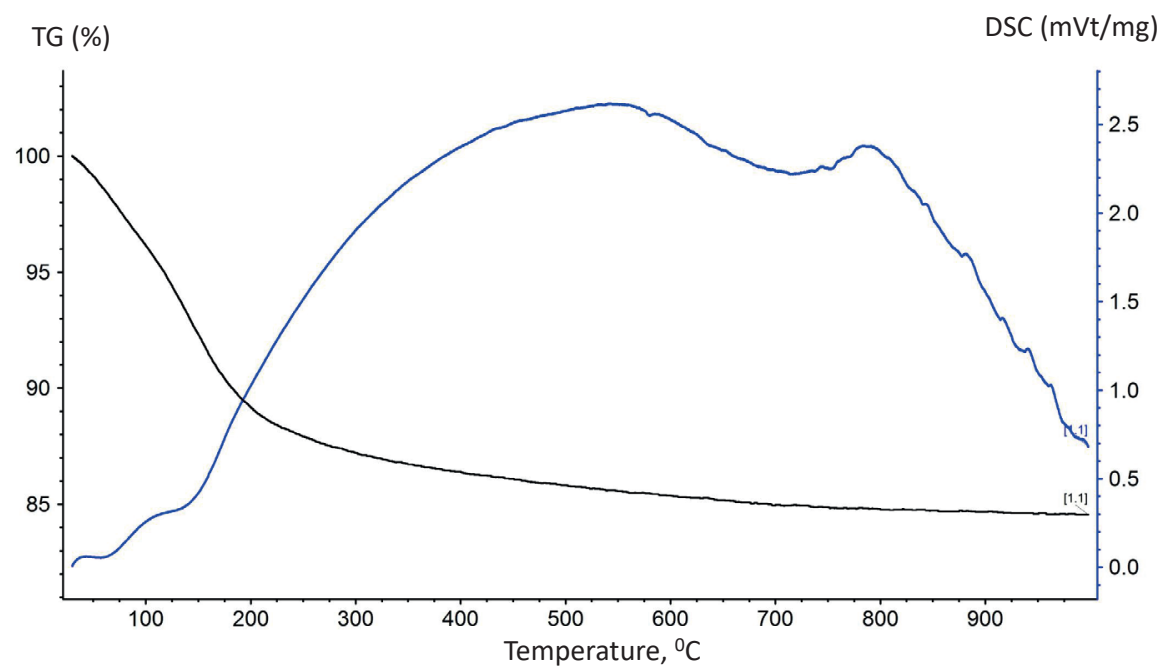

Fig. 12 Thermal analysis of AACC2 (based on calcined at $700^{\circ} \mathrm{C}$ Clay 2 ) hardened paste

hardened AACC (alkali activated clay cement) pastes. Both AACC1 and AACC2 based on Clays 1 and 2, respectively, include new formed hydrated sodium and aluminium silicate $\mathrm{Na}_{2} \mathrm{Al}_{2} \mathrm{Si}_{2.5} \mathrm{O}_{9} \cdot 6,2 \mathrm{H}_{2} \mathrm{O}$ belonging to the zeolite group.

The percentage of amorphous phase in hardened AACC1 paste was $38 \%$ and zeolite $3 \%$ (from the amount of crystalline phases), in AACC2 $-28 \%$ and $34 \%$, respectively.

Thermal analysis, Figs. 11 and 12 show 2 endothermic peaks for $\mathrm{AACC} 1$ in the ranges $30-95^{\circ} \mathrm{C}$ and $95-135^{\circ} \mathrm{C}$ with weight losses 3.14 and $1.25 \%$, respectively, and for $\mathrm{AACC} 2$ in the ranges $30-105^{\circ} \mathrm{C}$ and $105-200^{\circ} \mathrm{C}$ with weight losses 4.08 and $6.63 \%$.

FTIR spectra of the hardened pastes are shown in Fig. 13.
As can be seen the bands in the regions at 3373-3375 and $1641-1645 \mathrm{~cm}^{-1}$ attributed to stretching and the deformation vibrations of $\mathrm{OH}-$ and $\mathrm{H}-\mathrm{O}-\mathrm{H}$ groups from water molecules compared to calcined clay spectrum become more intensive and prove the formation of binder gel [21]. The bands located at $1024-1029 \mathrm{~cm}^{-1}$ reflecting in-plane and out-of-plane stretching $\mathrm{Si}-\mathrm{O}$ vibrations shifts to the 946-958 $\mathrm{cm}^{-1}$ reflecting vas $\mathrm{Si}-\mathrm{O}$ vibrations [22] due to structural arrangement as the reactive phase of the calcined clays transforms to the binder gel. Vibrations at $776 \mathrm{~cm}^{-1}$ attributed to quartz remain unchanged. The formation of zeolitic phase was proved by the bands at 733 and $656 \mathrm{~cm}^{-1}$ [23]. 


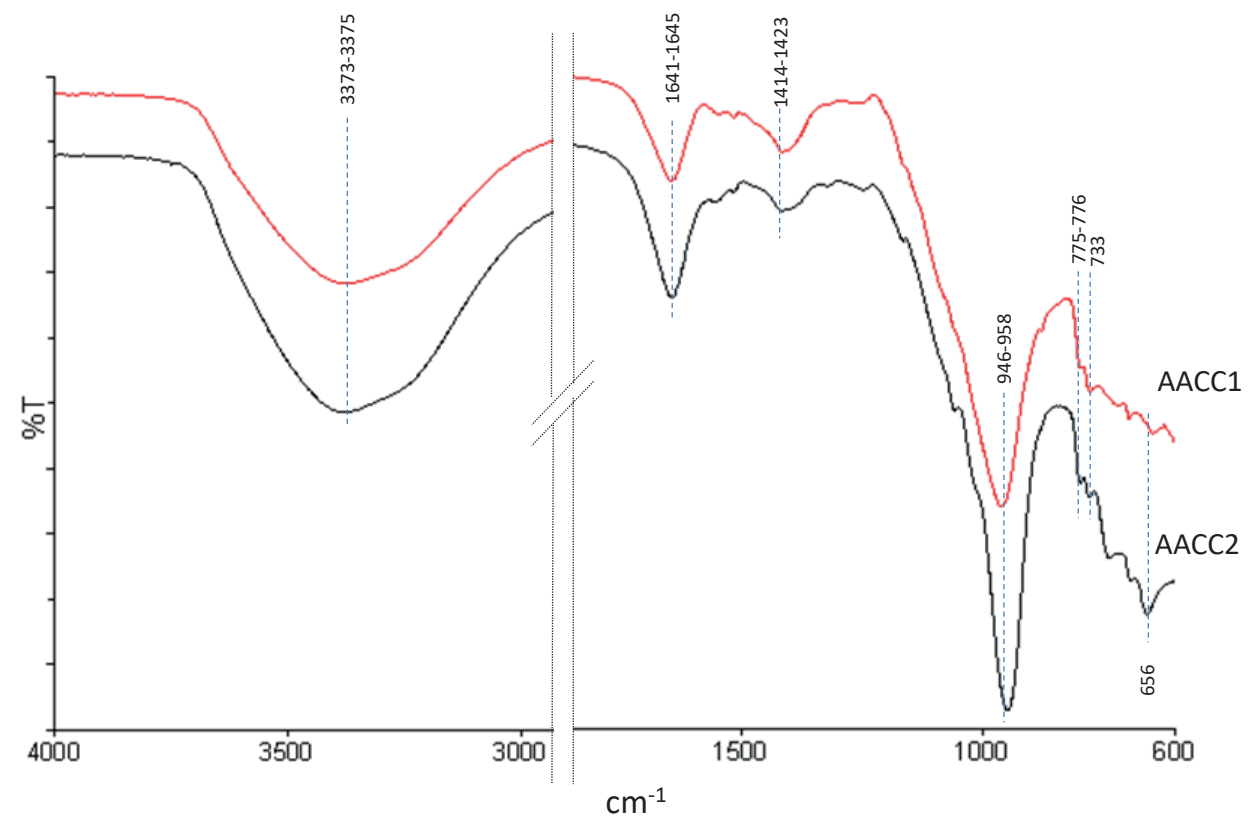

Fig. 13 FTIR spectra of AACC1 (based on calcined at $7000^{\circ}$ clay 1) and AACC2 (based on calcined at $700^{\circ} \mathrm{C}$ clay 2) hardened pastes

\subsection{Formation of calcined-clay- $\mathrm{NaOH}$ systems}

An analysis of the results obtained allows us to speculate that the following processes occur in the studied materials and reacted systems. According to XRD and thermal analysis results, a full decomposition of the clay minerals in both types of clay considered requires calcination at temperatures of higher than $600^{\circ} \mathrm{C}$. This explains the greater mechanical characteristics (Table 3) of the hardened pastes prepared from the clays at $700^{\circ} \mathrm{C}$ and $800^{\circ} \mathrm{C}$ as compared to those prepared at $600^{\circ} \mathrm{C}$. The completeness of the decomposition of the clay minerals at a definite calcination temperature provides the maximum possible formation of the reactive phase, and consequently, the greatest possible amount of binder gel during alkali activation. The percentage of the clay minerals is another influencing factor determining the amount of binder gel and its mechanical properties. The compressive strength of the hardened pastes prepared using Clay 2, which contains $23.14 \%$ clay minerals under raw conditions, is higher than those prepared using clay 1 , which contains $7.26 \%$ clay minerals under similar conditions. The higher content of the binder gel in pastes created using clay 2 compared to those created using clay 1 is confirmed through a TG analysis (Figs. 11 and 12), which reveals a higher weight loss within a temperature of up to $200{ }^{\circ} \mathrm{C}$, i.e., $10.81 \%$ and $4.39 \%$, respectively. Further, the total mass losses in the hardened materials prepared from clays 1 and 2 are $8.15 \%$ and $15.44 \%$, respectively. The results of the mechanical tests prove that the binder gel adequately covers and binds the non-reactive constituents, thus making a hardening of low-strength consolidated materials possible with a low clay mineral content for both montmorillonite/kaolinite and montmorillonite/chlorite based systems. The consolidation of the hardened paste of Clay 1 with a low clay mineral content may be supported by a slow reaction with alkali, resulting in good adhesion within the interfacial transition zone of a binder gel with feldspars. According to the XRD, FTIR spectroscopy, and DSC/TG results, the alkali activation of the calcined clays in pastes based on non-calcium clays results in the formation of a binder gel that is most likely N-(A)-S-H. The hydrothermal treatment of the reacted systems with calcined clays of $6 \mathrm{M} \mathrm{NaOH}$ creates favorable conditions for the crystallization of zeolite $\mathrm{Na}_{2} \mathrm{Al}_{2} \mathrm{Si}_{2.5} \mathrm{O}_{9} \cdot 6.2 \mathrm{H}_{2} \mathrm{O}$. It should be noted that it forms in pastes made of both types of clay, notwithstanding the differences between the types of clay minerals present. However, as demonstrated in the XRD analysis results, a higher percentage of clay minerals in Clay 2 resulted in the formation of a higher content of zeolite than that formed in pastes based on Clay 1 (Fig. 10).

To summarize, the clays studied were calcined at $700^{\circ} \mathrm{C}$, activated by $6 \mathrm{M} \mathrm{NaOH}$, and steam cured at $85^{\circ} \mathrm{C}$ for $6 \mathrm{~h}$, resulting in the formation of hardened pastes with compressive strengths of between 2.5 and $5 \mathrm{MPa}$, with zeolites as a reaction product. The properties obtained favor the use of such materials in ion-exchange processes, low-strength materials, and matrices for the solidification of toxic and radioactive wastes, particularly when considering the fact that the compressive strength required for 
cementitious waste forms varies significantly across different countries, i.e. $0.35 \mathrm{MPa}$ in France, 3.4 MPa in the US, $5 \mathrm{MPa}$ in the Russian Federation, $7 \mathrm{MPa}$ in the UK, and $10 \mathrm{MPa}$ in Switzerland [24].

\section{Conclusions}

Thermally treated clays are a valuable resource for producing different types of inorganic binders, including multipurpose alkali-activated mineral matrices. However, deposits of the most valuable high-grade kaolin clays are limited. Given that clays are extremely diverse resources in terms of their chemical and mineralogical compositions, feasibility studies focusing on the suitability of various types of clays are helpful for increasing the opportunity to obtain different types of materials for various purposes. In this study, the potential of applying calcined low-grade clays with 7.26 \% 2:1 layer-lattice minerals and $23.14 \% 1: 1+2: 1$ layer-lattice minerals as constituent clay

\section{References}

[1] Setareh, M., Darvas, R. "Concrete Structures", Springer, Cham, Switzerland, 2017.

http://doi.org/10.1007/978-3-319-24115-9

[2] Kurdowski, W. "Cement and Concrete Chemistry", Springer, Dordrecht, The Netherlands, 2013. http://doi.org/10.1007/978-94-007-7945-7

[3] Rakhimova, N. R., Rakhimov, R. Z. "Literature Review of Advances in Materials Used in Development of Alkali-Activated Mortars, Concretes, and Composites", Journal of Materials in Civil Engineering, 31(11), Article number: 03119002, 2019. http://doi.org/10.1061/(ASCE)MT.1943-5533.0002899

[4] Rakhimov, R. Z., Rakhimova, N. R., Gaifullin, A. R. "Influence of the addition of dispersed fine polymineral calcined clays on the properties of Portland cement paste", Advances in Cement Research, 29(1), pp. 21-32, 2017.

https://doi.org/10.1680/jadcr.16.00060

[5] Abdullahi, T., Harun, Z., Othman, M. H. D. "A review on sustainable synthesis of zeolite from kaolinite resources via hydrothermal process", Advanced Powder Technology, 28(8), 1827-1840, 2017. https://doi.org/10.1016/j.apt.2017.04.028

[6] Ji, Z., Pei, Y. "Bibliographic and visualized analysis of geopolymer research and its application in heavy metal immobilization: A review", Journal of Environmental Management, 231(2), pp. 256-267, 2019.

https://doi.org/10.1016/j.jenvman.2018.10.041

[7] Galán, E., Ferrell, R. E. "Genesis of clay minerals", In: Bergaya, F., Lagaly, G. (eds.), Handbook of Clay Science, Elsevier, Amsterdam, 2013, pp. 83-126.

https://doi.org/10.1016/B978-0-08-098258-8.00003-1 minerals for alkali-activated materials was investigated. The reported data demonstrate that, after thermal treatment at $700^{\circ} \mathrm{C}$, both types of clay become adequately reactive, forming low-strength hardened pastes with varying degrees of effectiveness. The main reaction products of calcined clays in $6 \mathrm{M} \mathrm{NaON}$ systems are a hydrated sodium aluminosilicate gel N-(A)-S-H and sodium and aluminium silicate $\mathrm{Na}_{2} \mathrm{Al}_{2} \mathrm{Si}_{2.5} \mathrm{O}_{9} \cdot 6,2 \mathrm{H}_{2} \mathrm{O}$ in both montmorillonite/chlorite and kaolinite/montmorillonite based alkali-activated systems. The zeolite content and compressive strengths are higher for alkali-activated clay pastes prepared from clay 2 with a higher percentage of clay minerals as compared to those prepared from clay 1.

The results obtained demonstrate that the current raw base material for zeolite-containing and low-strength alkali-activated clay cements can be expanded to include lowgrade calcined clays with a clay mineral content of lower than $25 \%$.

[8] Dietel, J., Warr, L. N., Bertmer, M., Steudel, A., Grathoff, G. H., Emmerich, K. "The importance of specific surface area in the geopolymerization of heated illitic clay", Applied Clay Science, 139, pp. 99-107, 2017.

https://doi.org/10.1016/j.clay.2017.01.001

[9] D'Elia, A., Pinto, D., Eramo, G., Giannossa, L. C., Ventruti, G., Laviano, R. "Effects of processing on the mineralogy and solubility of carbonate-rich clays for alkaline activation purpose: mechanical, thermal activation in red/ ox atmosphere and their combination", Applied Clay Science, 152, pp. 9-21, 2018. https://doi.org/10.1016/j.clay.2017.11.036

[10] Zhang, Z., Wang, H., Yao, X., Zhu, Y. "Effects of halloysite in kaolin on the formation and properties of geopolymers", Cement and Concrete Composites, 34(5), pp. 709-715, 2012. https://doi.org/10.1016/j.cemconcomp.2012.02.003

[11] Ma, Y., Yan, C., Alshameri, A., Qiu, X., Zhou, C., Li, D. "Synthesis and characterization of $13 \mathrm{X}$ zeolite from low- grade natural kaolin", Advanced Powder Technology, 25(2), pp. 495-499, 2014. https://doi.org/10.1016/j.apt.2013.08.002

[12] Mezni, M., Hamzaoui, A., Hamdi, N., Srasra, E. "Synthesis of zeolites from the low-grade Tunisian natural illite by two different methods", Applied Clay Science, 52(3), pp. 209-218, 2011. https://doi.org/10.1016/j.clay.2011.02.017

[13] Rakhimova, N. R., Rakhimov, R. Z., Morozov, V. P., Gaifullin, A. R., Potapova, L. I., Gubaidullina, A. M., Osin, Y. N. "Marl-based geopolymers incorporated with limestone: A feasibility study", Journal of Non-Crystalline Solids, 492, pp. 1-10, 2018. https://doi.org/10.1016/j.jnoncrysol.2018.04.015 
[14] Gharzouni, A., Ouamara, L., Sobrados, I., Rossignol, S. "Alkaliactivated materials from different aluminosilicate sources: Effect of aluminum and calcium availability", Journal of Non-Crystalline Solids, 484, pp. 14-25, 2018.

https://doi.org/10.1016/j.jnoncrysol.2018.01.014

[15] Nanganoa, L. T., Mbadcam, K. J., Kang, S. "Synthesis of Hydroxysodalite from Fine Fractions of SandyClay Loam Soil (Natural Aluminosilicate)", International Journal of Chem Tech Research, 9(6), pp. 725-732, 2016.

[16] Barbosa, V. F. F., MacKenzie, K. J. D., Thaumaturgo, C. "Synthesis and characterisation of materials based on inorganic polymers of alumina and silica: sodium polysialate polymers", International Journal of Inorganic Materials, 2(4), pp. 309-317, 2000. https://doi.org/10.1016/S1466-6049(00)00041-6

[17] Farmer, V. C. "Infrared spectroscopy", In: van Olephen, H., Fripiat, J. J. (eds.) Data Handbook for Clay Materials and Other Non-Metallic Minerals, Pergamon Press, Oxford, UK, 1979, pp. 285-337.

[18] Ferone, C., Liguori, B., Capasso, I., Colangelo, F., Cioffi, R., Cappelletto, E., Di Maggio, R. "Thermally treated clay sediments as geopolymer source material", Applied Clay Science, 107, pp. 195-204, 2015.

https://doi.org/10.1016/j.clay.2015.01.027
[19] Puertas, F., Palacios, M., Manzano, H., Dolado, J. S., Rico, A., Rodríguez, J. "A model for the C-A-S-H gel formed in alkali-activated slag cements", Journal of European Ceramic Society, 31(12), pp. 2043-2056, 2011. https://doi.org/10.1016/j.jeurceramsoc.2011.04.036

[20] El Hafid, K., Hajjaji, M. "Effects of the experimental factors on the microstructure and the properties of cured alkali-activated heated clay", Applied Clay Science, 116-117, pp. 202-210, 2015. https://doi.org/10.1016/j.clay.2015.03.015

[21] Madéjova, J. "FTIR techniques in clay mineral studies", Vibrational Spectroscopy, 31(1), pp. 1-10, 2003. https://doi.org/10.1016/S0924-2031(02)00065-6

[22] Garcia-Lodeiro, I., Palomo, A., Fernández- Jiménez, A., Macphee, D. E. "Compatibility studies between N-A-S-H and C-A-S-H gels. Study in the ternary diagram $\mathrm{Na}_{2} \mathrm{O}-\mathrm{CaO}-\mathrm{Al}_{2} \mathrm{O}_{3}-\mathrm{SiO}_{2}-\mathrm{H}_{2} \mathrm{O}$, Cement and Concrete Research, 41(9), pp. 923-931, 2011. https://doi.org/10.1016/j.cemconres.2011.05.006

[23] Karge, H. G. "Characterization by IR spectroscopy", In: Robson H., Lillerud, K. P. (eds.) Verified Synthesis of Zeolite Materials, 2 ed., Elsevier Science, Amsterdam, The Netherlands, 2001, pp. 69-71. https://doi.org/10.1016/B978-044450703-7/50113-7

[24] Abdel Rahman, R. O., Rakhimov, R. Z., Rakhimova, N. R., Ojovan, M. I. "Cementitious Materials for Nuclear Waste Immobilization", Wiley, Chichester, UK, 2015. http://doi.org/10.1002/9781118511992 